\title{
Interval Between Cancer Diagnosis and Radiotherapy - An Independent Prognostic Factor of Survival in Patients Irradiated for Bone Metastases from Kidney Cancer
}

\author{
DIRK RADES ${ }^{1}$, RAPHA HAUS ${ }^{1}$, STEFAN JANSSEN ${ }^{1,2}$ and STEVEN E. SCHILD ${ }^{3}$ \\ ${ }^{1}$ Department of Radiation Oncology, University of Lübeck, Lübeck, Germany; \\ ${ }^{2}$ Medical Practice for Radiotherapy and Radiation Oncology, Hannover, Germany; \\ ${ }^{3}$ Department of Radiation Oncology, Mayo Clinic, Scottsdale, AZ, U.S.A.
}

\begin{abstract}
Background/Aim: Cancer patients with metastatic disease require personalized treatment regimens. This study was performed to identify prognostic factors for overall survival (OS) following irradiation of bone metastases from kidney cancer. Patients and Methods: Data of 29 patients irradiated for bone metastases from kidney cancer were retrospectively evaluated. Ten factors were analyzed, including age, gender, performance score, interval from diagnosis of kidney cancer until radiotherapy for bone metastases, visceral metastases, other bone metastases, metastatic sites, number of irradiated sites, surgery of irradiated sites and systemic treatment prior to radiotherapy. Results: Using univariate analyses, a longer interval from diagnosis of kidney cancer radiotherapy was associated with better $O S(p=0.012)$. Using Cox regression analysis, this factor remained significant (risk ratio=3.54, $p=0.012$ ). Conclusion: The interval from diagnosis of kidney cancer until radiotherapy is an independent prognostic factor associated with OS following irradiation of bone metastases from kidney cancer. This type of data can help personalize radiation programs.
\end{abstract}

Cancer patients with metastatic disease require personalized treatment that meets the needs of each patient. This includes an assessment of the patient's expected remaining lifespan. For patients with a poor expected survival time, the

This article is freely accessible online.

Correspondence to: Dirk Rades, Department of Radiation Oncology, University of Lübeck, Lübeck, Ratzeburger Allee 160, 23562 Lübeck, Germany. Tel: +49 45150045401, Fax: +49 45150045404, e-mail: rades.dirk@gmx.net

Key Words: Bone metastases, kidney cancer, radiotherapy, prognostic factor, overall survival. treatment regimen should be short so they spend as little time as possible receiving treatment. In patients with a favorable survival prognosis, one must account for the fact that these patients may live long enough to be at risk of experiencing a local recurrence. Thus, prognostic factors that help physicians estimate a patient's survival time are important to choose the most appropriate treatment regimen.

In radiation oncology, the most frequent types of metastases include brain and bone metastases. For example, bone metastases can occur in up to $40 \%$ of patients with kidney cancer during their lives $(1,2)$. For these patients, various radiotherapy programs are available including singlefraction, short-course multi-fraction (over approximately 1 week) and longer-course (over 2-4 weeks) programs (2). Patients with a poor survival appear as good candidates for single-fraction or short-course radiotherapy. Those patients with favorable prognoses can benefit from longer-course programs that result in better long-term local control of irradiated bone metastases $(2,3)$. Therefore, it is important to be able to estimate a patient's overall survival (OS) time prior to the start of radiotherapy. This can be facilitated with the clear understanding of significant prognostic factors.

Malignant tumors vary considerably regarding their biological behavior. Therefore, it is important to identify prognostic factors in patients with bone metastases for each tumor type. This has already been performed for other situations, such as metastatic spinal cord compression (MSCC) and brain metastases (4-12). The present study was performed to identify independent prognostic factors associated with OS in patients irradiated for bone metastases from kidney cancer.

\section{Patients and Methods}

This retrospective study evaluated the data of 29 patients irradiated for bone metastases from kidney cancer without MSCC with respect to OS. The study was approved by the local ethics committee (reference: 18-254A). All patients received multifraction radiotherapy 
Table I. Distribution of the ten potential predictors of survival.

\begin{tabular}{lc}
\hline & $\begin{array}{c}\text { Number of patients } \\
(\%)\end{array}$ \\
& \\
\hline Age at start of radiotherapy & $15(52)$ \\
$\leq 70$ Years & $14(48)$ \\
$\geq 71$ Years & \\
Gender & $8(28)$ \\
Female & $21(72)$ \\
Male & \\
ECOG performance score & $18(62)$ \\
$0-1$ & $10(34)$ \\
$\geq 2$ & $1(3)$ \\
Unknown & \\
Interval from diagnosis of kidney & \\
cancer until start of radiotherapy & $16(55)$ \\
$\leq 8$ Months & $13(45)$ \\
$\geq 9$ Months & $7(24)$ \\
Visceral metastases & $22(76)$ \\
No & \\
Yes & $8(28)$ \\
Other bone metastases & $21(72)$ \\
No & \\
Yes & $10(34)$ \\
Type of metastatic site & $10(34)$ \\
Spinal only & $9(31)$ \\
Extraspinal only & \\
Both & $12(41)$ \\
Number of irradiated sites & $17(59)$ \\
$\geq 2$ & $16(55)$ \\
Surgery prior to radiotherapy & $13(45)$ \\
No & $10(34)$ \\
Systemic treatment prior to radiotherapy & $19(66)$ \\
No & \\
Yes & \\
\hline & \\
& \\
&
\end{tabular}

ECOG: Eastern Cooperative Oncology Group.

with 5-6×4.0 Gy $(n=2), 10 \times 3.0$ Gy $(n=5), 12-13 \times 3.0$ Gy $(n=8), 14-$ $15 \times 2.5 \mathrm{~Gy}(\mathrm{n}=11)$ or $20 \times 1.8-2.0 \mathrm{~Gy}(\mathrm{n}=3)$. Ten factors were analyzed for potential associations with OS, including i) age ( $\leq 70 \mathrm{vs} . \geq 71$ years, median $=70$ years), ii) gender, iii) Eastern Cooperative Oncology Group (ECOG) performance score (0-1 vs. $\geq 2)(13)$, iv) interval from diagnosis of kidney cancer until start of radiotherapy for bone metastases ( $\leq 8 v s . \geq 9$ months, median $=8$ months), v) visceral metastases prior to radiotherapy (no $v s$. yes), vi) other bone metastases prior to radiotherapy (no $v s$. yes), vii) type of metastatic sites (spinal only $v s$. extraspinal only $v s$. both), viii) number of irradiated metastatic sites $(1 v s . \geq 2)$, ix) surgery of irradiated bone metastases prior to radiotherapy (no vs. yes) and $\mathrm{x}$ ) systemic treatment prior to radiotherapy (no $v s$. yes). The distribution of these factors is given in Table I.

Statistical analyses were initially performed using the KaplanMeier method and the log-rank test (univariate analyses). Subsequently, those factors found significant on univariate analysis $(p<0.05)$ were included in a multivariate analysis (Cox regression) for evaluation with respect to independence.

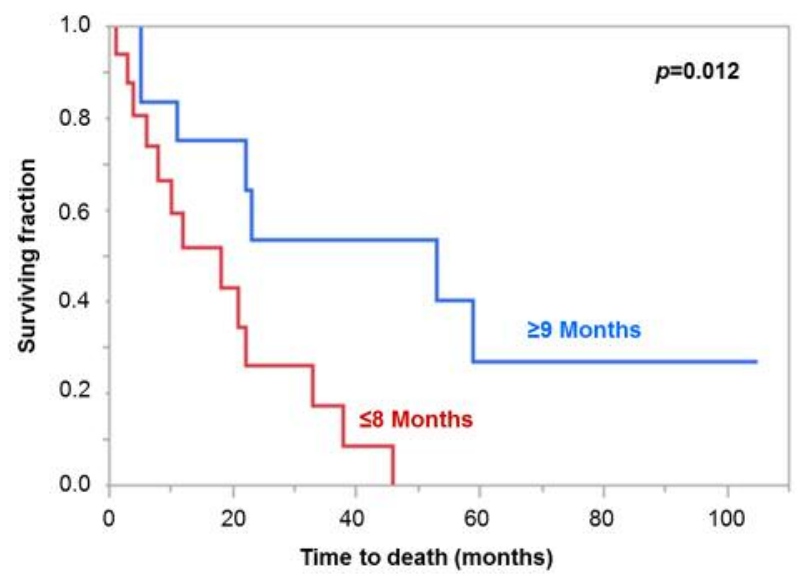

Figure 1. Kaplan-Meier curves for kidney cancer patients with respect the the interval between first diagnosis of cancer and start of radiotherapy. Improved survival was identified for patients with longer interval ( $\geq 9$ months) compared to the shorter interval ( $\leq 8$ months). The p-value was calculated using the log-rank test.

\section{Results}

Median follow up of the entire cohort was 17 months (range $=1-105$ months). The OS rates at 6 months and 12 months were $78 \%$ and $63 \%$, respectively. Using univariate analyses, only a longer interval ( $\geq 9$ months) from the first diagnosis of kidney cancer to the start of radiotherapy was significantly associated with a better OS ( $p=0.012$, Figure 1$)$. The results of the entire univariate analyses are summarized in Table II. In the subsequent Cox regression analysis, the interval from the first diagnosis of kidney cancer to the start of radiotherapy remained significant (risk ratio $=3.54$, 95\%Confidence Interval=1.31-11.24, $p=0.012$ ).

\section{Discussion}

Since the survival of patients with metastatic kidney cancer is poor, a great amount of data from preclinical and clinical research has been gathered (14-19). In addition to the development of new drugs, personalized treatment is another important approach. This includes selecting the most appropriate radiation program for each patient. A personalized approach ideally accounts for the patient's expected survival to avoid either over- or under-treatment. A clear understanding of prognostic factors for survival can help physicians select the optimal program for each patient. For optimizing the personalized radiation treatment, the metastatic site as well as the tumor type should be considered. This study was performed to identify significant prognostic factors for survival following irradiation of bone metastases from kidney cancer. 
Table II. Overall survival (OS) rates of the 10 investigated factors (univariate analyses).

\begin{tabular}{|c|c|c|c|}
\hline \multirow[t]{2}{*}{ Factor } & \multicolumn{2}{|c|}{ Overall survival } & \multirow[t]{2}{*}{$p$-Value } \\
\hline & $\begin{array}{l}6 \text { months } \\
(\%)\end{array}$ & $\begin{array}{l}12 \text { months } \\
(\%)\end{array}$ & \\
\hline \multicolumn{4}{|c|}{ Age at start of radiotherapy } \\
\hline$\leq 70$ Years & 78 & 70 & \\
\hline$\geq 71$ Years & 79 & 55 & 0.28 \\
\hline \multicolumn{4}{|l|}{ Gender } \\
\hline Female & 88 & 63 & \\
\hline Male & 75 & 63 & 0.76 \\
\hline \multicolumn{4}{|c|}{ ECOG performance score } \\
\hline $0-1$ & 88 & 69 & \\
\hline$\geq 2$ & 60 & 48 & 0.28 \\
\hline \multicolumn{4}{|c|}{$\begin{array}{l}\text { Interval from diagnosis of kidney } \\
\text { cancer until start of radiotherapy }\end{array}$} \\
\hline$\leq 8$ Months & 74 & 52 & \\
\hline$\geq 9$ Months & 83 & 75 & 0.012 \\
\hline \multicolumn{4}{|l|}{ Visceral metastases } \\
\hline No & 86 & 69 & \\
\hline Yes & 76 & 61 & 0.66 \\
\hline \multicolumn{4}{|c|}{ Other bone metastases } \\
\hline No & 67 & 50 & \\
\hline Yes & 81 & 66 & 0.64 \\
\hline \multicolumn{4}{|c|}{ Type of metastatic site } \\
\hline Spinal only & 78 & 56 & \\
\hline Extraspinal only & 80 & 80 & \\
\hline Both & 78 & 47 & 0.39 \\
\hline \multicolumn{4}{|c|}{ Number of irradiated sites } \\
\hline 1 & 82 & 73 & \\
\hline$\geq 2$ & 76 & 55 & 0.11 \\
\hline \multicolumn{4}{|c|}{ Surgery prior to radiotherapy } \\
\hline No & 75 & 61 & \\
\hline Yes & 82 & 64 & 0.96 \\
\hline \multicolumn{4}{|c|}{$\begin{array}{l}\text { Systemic treatment prior to } \\
\text { radiotherapy }\end{array}$} \\
\hline No & 79 & 66 & \\
\hline Yes & 78 & 61 & 0.75 \\
\hline
\end{tabular}

ECOG: Eastern Cooperative Oncology Group, bold $p$-value=significant

A few scoring systems for estimating the survival of patients irradiated for bone metastases already exist. One of these scores was developed in patients with spinal metastases (20). Based on the performance score, the type of primary tumor and presence of visceral metastases, three groups were created with survival times of median 3,9 and 18.7 months. However, this score may not be useful for extraspinal bone metastases (20). More recently, other scores for patients irradiated for bone metastases were created $(21,22)$. One of these scoring systems was developed in patients with spinal and/or extraspinal bone metastases (21). Gender, primary tumor type, performance score, visceral metastases and two self-rating tools considering general health and quality of life were identified as significant prognostic factors. As this scoring system was very complex, a simpler system based only on performance score and primary tumor type was provided in the same report (21). Another scoring system was created from data of 1,043 patients with spinal metastases including only patients with MSCC (22). This score may not be applicable to extraspinal bone metastases. The most recent scoring tool for estimation of survival following irradiation of bone metastases was limited to symptomatic metastases of the long bones and may not be useful for patients with spinal lesions (23). Moreover, none of these studies was performed in patients with bone metastases from a specific tumor type. The present study focused on patients with kidney cancer and determined that the interval from diagnosis of kidney cancer to the start of radiotherapy for bone metastases was significantly associated with OS in both univariate and multivariate analyses. This independent prognostic factor may help physicians select a more appropriate personalized radiotherapy program for each patient. Patients with a longer interval ( $\geq 9$ months), which was associated with better survival, should be considered for longer-course radiotherapy programs and patients with shorter intervals ( $\leq 8$ months) for shorter programs. However, the retrospective design of this study may have led to inclusion of hidden selection biases that should be considered when applying this information. Moreover, since all patients received multi-fraction radiotherapy, the findings of this study may not be applicable to patients treated with single-fraction irradiation.

In conclusion, the interval between first diagnosis of kidney cancer and radiotherapy of bone metastases appears to be an independent prognostic factor for OS after irradiation of bone metastases from kidney cancer. This knowledge can help physicians personalize radiation programs, and this prognostic factor can potentially improve the stratification of patients in future clinical trials.

\section{Conflicts of Interest}

On behalf of all Authors, the corresponding Author states that there are no conflicts of interest related to this study.

\section{Authors' Contributions}

D.R., R.H., S.J. and S.E.S participated in the design of the study. D.R., R.H. and S.J. provided data. D.R. and S.E.S. performed the analyses of the data and drafted the manuscript, which has been reviewed and approved by all authors.

\section{References}

1 Coleman RE: Clinical features of metastatic bone disease and risk of skeletal morbidity. Clin Cancer Res 12: 6243s-6249s, 2006. PMID: 17062708. DOI: 10.1158/1078-0432.CCR-06-0931

2 Rades D, Schild SE and Abrahm JL: Treatment of painful bone metastases. Nat Rev Clin Oncol 7: 220-229, 2010. PMID: 20234353. DOI: $10.1038 /$ nrclinonc. 2010.17 
3 Chow E, Zeng L, Salvo N, Dennis K, Tsao M and Lutz S: Update on the systematic review of palliative radiotherapy trials for bone metastases. Clin Oncol (R Coll Radiol) 24: 112-124, 2012. PMID: 22130630. DOI: 10.1016/j.clon.2011.11.004

4 Rades D, Hansen HC, Janssen S and Schild SE: Diagnosisspecific WBRT-30-CRC score for estimating survival of patients irradiated for brain metastases from colorectal cancer. Anticancer Res 39: 2569-2574, 2019. PMID: 31092454. DOI: 10.21873/ anticanres. 13379

5 Hansen HC, Janssen S, Schild SE and Rades D: Estimating survival of patients with metastatic renal cell carcinoma receiving whole-brain radiotherapy with a new tool. Anticancer Res 39: 2091-2095, 2019. PMID: 30952754. DOI: 10.21873/ anticanres. 13321

6 Rades D, Hansen HC, Schild SE and Janssen S: A new diagnosis-specific survival score for patients to be irradiated for brain metastases from non-small cell lung cancer. Lung 197: 321-326, 2019. PMID: 30927058. DOI: 10.1007/s00408-01900223-6

7 Rades D, Sehmisch L, Hansen HC, Dziggel L, Janssen S and Schild SE: Comparison of diagnosis-specific survival scores for patients with cerebral metastases from malignant melanoma including the new WBRT-30-MM. Anticancer Res 39: 15011505, 2019. PMID: 30842188. DOI: 10.21873/anticanres.13268

8 Rades D, Dziggel L, Manig L, Janssen S, Khoa MT, Duong VN, Khiem VH and Schild SE: Predicting survival after whole-brain irradiation for cerebral metastases in patients with cancer of the bladder. In Vivo 32: 633-636, 2018. PMID: 29695570. DOI: 10.21873/invivo.11285

9 Rades D, Sondermann L, Motisi L, Janssen S, Cacicedo J and Schild SE: Prognostic factors and a survival score in patients irradiated for metastatic epidural spinal cord compression from urothelial carcinoma of the bladder. Anticancer Res 38: 68416846, 2018. PMID: 30504399. DOI: 10.21873/anticanres.13058

10 Rades D, Douglas S, Veninga T, Stalpers LJ, Bajrovic A, Rudat $\mathrm{V}$ and Schild SE: Prognostic factors in a series of 504 breast cancer patients with metastatic spinal cord compression. Strahlenther Onkol 188: 340-345, 2012. PMID: 22354333. DOI: 10.1007/s00066-011-0061-4

11 Rades D, Douglas S, Veninga T, Bajrovic A, Stalpers LJ, Hoskin PJ, Rudat V and Schild SE: Metastatic spinal cord compression in non-small cell lung cancer patients: Prognostic factors in a series of 356 patients. Strahlenther Onkol 188: 472-476, 2012. PMID: 22361746. DOI: 10.1007/s00066-012-0086-3

12 Rades D, Douglas S, Veninga T, Poortmans P, Bajrovic A, Hoskin PJ, Rudat V and Schild SE: Prognostic factors for local control and survival in patients with spinal cord compression from myeloma. Strahlenther Onkol 188: 628-631, 2012. PMID: 22410834. DOI:10.1007/s00066-012-0077-4

13 Oken MM, Creech RH, Tormey DC, Horton J, Davis TE, McFadden ET and Carbone PP: Toxicity and response criteria of the Eastern Cooperative Oncology Group. Am J Clin Oncol 5: 649-655, 1982. PMID: 7165009.

14 Boegemann M, Hubbe M, Thomaidou D, Blackburn S, BentEnnakhil N, Wood R and Bargo D: Sunitinib treatment modification in first-line metastatic renal cell carcinoma: Analysis of the STAR-TOR registry. Anticancer Res 38: 64136422, 2018. PMID: 30396966. DOI: 10.21873/anticanres.13002
15 Rutz J, Juengel E, Euler S, Maxeiner S, Justin S, Roos F, Chun FK and Blaheta RA: Chronic sulforaphane application does not induce resistance in renal cell carcinoma cells. Anticancer Res 38: 6201-6207, 2018. PMID: 30396938. DOI: 10.21873/ anticanres. 12974

16 Santoni M, Piva F, De Giorgi U, Mosca A, Basso U, Santini D, Buti S, Lolli C, Terrone C, Maruzzo M, Iuliani M, Bersanelli M, Conti A, Mazzucchelli R, Montironi R, Burattini L and Berardi $\mathrm{R}$ : Autophagic gene polymorphisms in liquid biopsies and outcome of patients with metastatic clear cell renal cell carcinoma. Anticancer Res 38: 5773-5782, 2018. PMID: 30275199. DOI: 10.21873 /anticanres.12916

17 Isono M, Sato A, Asano T, Okubo K and Asano T: Evaluation of therapeutic potential of phenoxodiol, a novel isoflavone analog, in renal cancer cells. Anticancer Res 38: 5709-5716, 2018. PMID: 30275191. DOI: 10.21873/anticanres.12908

18 Vuorinen RL, Paunu N, Turpeenniemi-Hujanen T, Reunamo T, Jekunen A, Kataja V, Sintonen H, Purmonen T and KellokumpuLehtinen PL: Sunitinib first-line treatment in metastatic renal cell carcinoma: Costs and effects. Anticancer Res 39: 55595564, 2019. PMID: 31570450. DOI: 10.21873/anticanres.13749

19 Hara T, Miyake H, Hinata N and Fujisawa M: Inhibition of tumor growth and sensitization to sunitinib by RNA interference targeting programmed death-ligand 1 in mouse renal cell carcinoma RenCa model. Anticancer Res 39: 4737-4742, 2019. PMID: 31519573. DOI: 10.21873/anticanres.13656

20 van der Linden YM, Dijkstra SP, Vonk EJ, Marijnen CA and Leer JW, Dutch Bone Metastasis Study Group: Prediction of survival in patients with metastases in the spinal column: results based on a randomized trial of radiotherapy. Cancer 103: 320328, 2005. PMID: 15593360 DOI: 10.1002/cncr.20756

21 Westhoff PG, de Graeff A, Monninkhof EM, Bollen L, Dijkstra SP, van der Steen-Banasik EM, van Vulpen M, Leer JW, Marijnen CA, van der Linden YM and Dutch Bone Metastasis Study Group: An easy tool to predict survival in patients receiving radiation therapy for painful bone metastases. Int $\mathbf{J}$ Radiat Oncol Biol Phys 90: 739-747, 2014. PMID: 25260489 DOI: 10.1016/j.ijrobp.2014.07.051

22 Bollen L, van der Linden YM, Pondaag W, Fiocco M, Pattynama BP, Marijnen CA, Nelissen RG, Peul WC and Dijkstra PD: Prognostic factors associated with survival in patients with symptomatic spinal bone metastases: a retrospective cohort study of 1,043 patients. Neuro Oncol 16: 991-998, 2014. PMID: 24470544. DOI: $10.1093 /$ neuonc/not318

23 Willeumier JJ, van der Linden YM, van der Wal CWPG, Jutte PC, van der Velden JM, Smolle MA, van der Zwaal P, Koper P, Bakri L, de Pree I, Leithner A, Fiocco M and Dijkstra PDS: An easy-to-use prognostic model for survival estimation for patients with symptomatic long bone metastases. J Bone Joint Surg Am 100: 196-204, 2018. PMID: 29406340. DOI: 10.2106/JBJS. 16.01514 